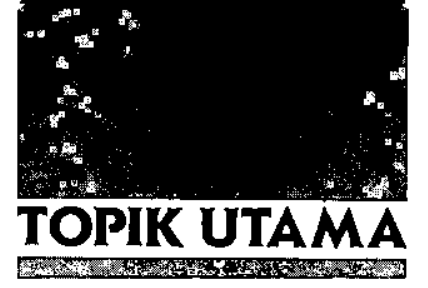

\title{
Pemilu : \\ Tuntutan Konstitusi dan Gugatan Parpol
}

Demam Pemilu menerobos kemana-mana. Kampus yang selalu dikenal sebagai lembaga ilmiahpun terbawa oleh arus demam ini. Setelah beberapa waktu sebelumnya FISIPOL UGM menyelenggarakan Seminar yang berlangsung hangat. UII pun melalui Jurusan HTN pada Fakultas Hukum menyelenggarakan Seminar di bawah thema PEMILU DALAM RANGKA MENGISI UUD 1945. Seminar yang berlangsung di kampus UII Jalan Cik Ditiro tanggal 22 Agustus 1991 itu berlangsung sangat meriah dari pagi sampai sore. Kemeriahan itu memang sudah diduga jauh sebelum seminar berlangsung sebab, disamping thema tentang Pemilu memang sedang hangat. para pembicara pun yang dihadirkan sebagai pemrasaran sudah sangat dikenal sebagai pembicara-pembicara yang berbobot. Dari Parpol dan Golkar hadir Ismail Hasan Metareum (Ketua Umum PPP), Soeryadi (Ketua Umum PDI), dan Slamet Effendi Yusuf (Ketua Departemen Pemuda Golkar) Sedangkan dari kampus datang Prof. Dr. Sri Soemantri (guru besar HTN) serta Dahlan Thaib (Ketua Jurusan Hukum Tata Negara pada Fakultas Hukum UII).

Seminar dibagi dua sessi yang masing-masingnya menekankan pada dimensi yang berbeda; sessi pertama menekankan pada gagasan-gagasan ideal-teoritik sedangkan sessi kedua menekankan pada masalah-masalah di lapangan.

\section{Penggarisan Konstitusi}

Dahlan Thaib yang berbicara dibawah topik "Pemilu Ditinjau Dari Landasan Konstitusional UUD 1945" mengemukakan bahwa tidak ada satu kalimatpun di dalam UUD 1945 yang memerintahkan secara tersurat tentang Pemilu. Ini berbeda dengan UUDS 1950 yang didalam ps. 35 menggariskan bahwa "Kemauan rakyat adalah dasar kekuasaan penguasa, kemauan itu dinyatakan dalam pemilihan berkala yang jujur dan yang dilakukan menurut hak pilih yang bersifat umum dan berkesamaan...". Penggarisan ini tak dapat dibantah merupakan perintah yang gamblang tentang dilembagakannya Pemilu sebagai bagian dari realisasi paham kedaulatan rakyat.

Kendati di dalam UUD 1945 tidak ada perintah tersurat tentang Pemilu namun tak boleh ada anggapan bahwa hidup bernegara dibawah UUD 1945 ini tidak mengenal Pemilu. Perintah-perintah tersirat ditunjukkan oleh Dahlan Thaib untuk meyakinkan ini. Lihatlah misalnya penegasan pasal 1 ayat (2) yang menyatakan bahwa kedaulatan 
adalah ditangan rakyat dan dilakukan sepenuhnya oleh MPR. "Nah anggota MPR ini sebagian harus diisi melalui Pemilu", tandasnya. Selanjutnya ditunjuk pula oleh Dahlan Thaib garis tegas pasal 2 (1) dan pasal 19 (1). Pasal 2 (1) yang berbunyi "MPR terdiri atas anggota-anggoa DPR ditambah dengan utusan daerah dan golongangolongan" dan pasal 19. (1) yang berbunyi "Susunan DPR ditetapkan dengan UU" telah melahirkan UU tentang Pemilu sebagai salah satu cara untuk menentukan wakil-wakil rakyat yang akan duduk di DPR. Dari ketentuan-ketentuan tersirat konstitusional ini kemudian lahir berbagai produk legislatif tentang Pemilu. (Lihat : Dahlan Thaib, Pemilu Ditinjau Dari Landasan Konstitusional UUD 1945).

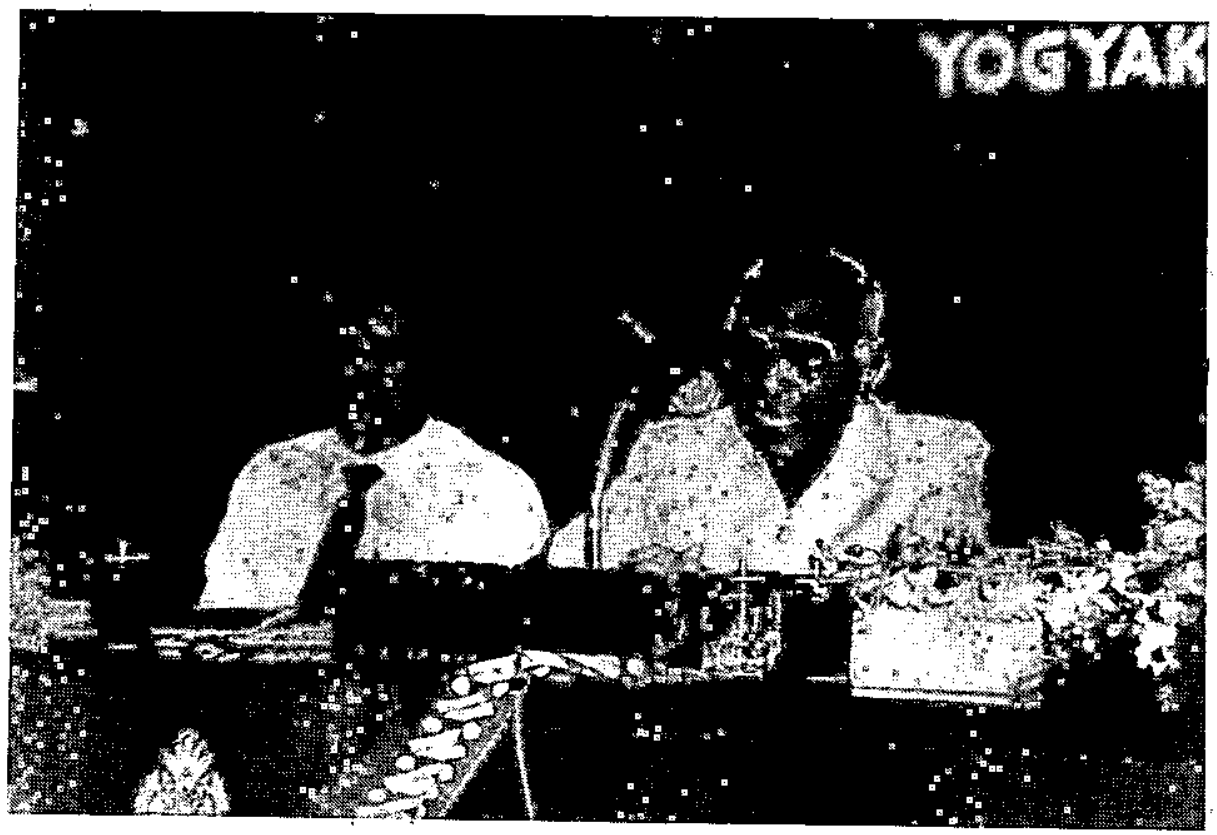

'Dahlan Thaib dan Sri Soemantri, landasan konstitusional;

\section{Batas jumlah partai.}

Sementara itu Sri Soemantri tidak hanya mengkaitkan dengan cara pengisian lembaga perwakilan bagi konsekuensi adanya Pemilu ini. Guru besar Unpad ini lebih jauh mengkaitkan adanya Pemilu dengan ketentuan tentang kemerdekaan berserikat dan berkumpul sebagaimana dimuat dalam pasal 28 UUD 1945. Dikatakannya bahwa adanya konstitusi adalah untuk membuat pembatasan kekuasaan dalam negara sebab tanpa itu kekuasaan akan dijalankan sewenang-wenang. Pasal 28 tidak menonjolkan "hak-hak" yang individualistik tetapi lahir dalam rumusan "kemerdekaan". Lahirnya Parpol dan Golkar, kata Soemantri, adalah salah satu realisasi dari kemerdekaan berserikat. 
Salah satu pertanyaan mendasar yang diajukan Soemantri adalah ini : Apakah kemerdekaan berserikat mengandung arti adanya kebebasan untuk mendirikan . organisasi-organisasi (termasuk orpol) tanpa batas ? Dengan kata lain : Apakah dengan pasal 28 itu dapat dianut sistem banyak partai yang dapat bertarung dalam Pemilu?

Dari sudut UU itu sendiri, meskipun tidak tegas, dapat disimpulkan bahwa UUD 1945 mengakui ada dan berlakunya kemerdekaan untuk membentuk berbagai organisasi, termasuk organisasi politik. Itulah sebabnya pada periode pertama berlakunya UUD 1945 pernah dianut sistem banyak partai yang menyusul lahirnya Maklumat No. X dan Maklumat Pemerintah tertanggal 1 Nopember 1945. Sistem multi partai yang memberi peranan sangat menentukan bagi badan legislatif (waktu itu KNIP) ini kemudian tetap dianut di dalam UUDS 1950 yang berlaku sejak tgl. 17 Agustuts 1950. Tetapi sistem pemerintahan parlementer yang bergandeng dengán sistem multi partai itu telah menjadi sebab tidak adanya stabilitas pemerintah dan stabilitas politik sehingga kabinet jatuh bangun dalam waktu yang relatif pendekpendek. Masih kata Soemantri, keadaan yang demikian itu dipergunakan oleh Presiden untuk menggantikan berlakunya demokrasi terpimpin yang kemudian disusul dengan Penpres No. 7/1959 tentang penyederhanaan jumlah parpol sehingga menjadi sepuluh parpol. Orde Baru melanjutkan garis pembatasan jumlah parpol ini sehingga pada Pemilu 1971 hanya tampil 10 organisasi kekuatan politik. "Bedanya, kalau pada masa demokrasi terpimpin di dalam sepuluh parpol itu termasuk Partindo dan PKI maka pada masa Orba kedua parol itu sudah dibubarkan sedangkan Murba dihidupkan kembali dan Golkar disertakan sebagai kontestan baru". Penyederhanaan ini diperketat lagi setelah Pemilu 1971 yang dikristalisasikan dengan keluarnya UU No. 3 Tahun 1975 yang membenarkan hanya ada tiga orpol.

Jadi pembatasan jumlah parpol yang kini hanya tiga macam itu berangkat dari kenyataan historik bahwa sistem multi partai telah menyebabkan labilitas pemerintahan dan politik sehingga bangsa Indoneșia tidak dapat melakukan pembangunan.

Cukupkah dengan tiga orpol bagi Indonesia ? Belakangan ini ada suara-suara yang menghendaki adanya parpol baru karena ketiga orpol yang sekarang ada dipandang belum mencerminkan aspirasi politik. "Dilihat dari UUD 1945, yaitu kemerdekaan berserikat pasal 28 memberikan indikasi adanya atau dimungkinkannya adanya lebih dari dua partai politik," kata Soemantri. Tapi, demikian ia menambahkạn, adanya sistem pertanggung jawaban Presiden kepada MPR yang memungkinkan pencabutan mandat dan pemberhentian Presiden oleh MPR dalam masa jabatan dapat membawa akibat labilitas politik dan pemerintahan jika terlalu banyak partai, seperti yang terjadi pada masa-masa berlakunya UUDS 1950 . Oleh sebab itu upaya penambahan orpol baru harus memperhatikan faktor ini. "Di samping itu untuk dimungkinkan adanya lebih dari dua parpol tergantung dari kemauan politik pembuatan undangundang untuk mengubah UU No. 3 tahun 1975", tandasnya lagi. (Lihat: Soemantri, Menelusuri UU Pemilu Serta UU Parpol dan Golkar). 


\section{Sistem Distrik Ditolak.}

Masalah sistem Pemilu yang belakangan ini banyak juga disorot oleh sementara pakar muncul juga dalam prasaran Sri Soemantri dan Afan Gaffar. Setelah menguraikan panjang lebar tentang berbagai sistem Pemilu (Lihat : Sri Soemantri, ibid) disertai kekuatan dan kelemahan masing-masing Sri Soemantri menyatakan bahwa Sistem Pemilu di Indonesia pada asasnya adalah sistem proporsional sebagaimana bisa dilihat pada pasal 5 (1) dan penjelasan Umum UU No. 2 Tahun 1985. Tetapi sebenarnya sistem proporsional yang dianut tidaklah murni. Sebab didalam UU itu ada juga unsur sistem distriknya sebagaimana terlihat pada pasal 5 (2) dan pasal 6. Kedua pasal tersebut memberi konsekuensi bahwa pembagian kursi untuk setiap daerah pemilihan yang digunakan pertama-tama adalah perhitungan jumlah daerah Tingkat II yang ada di daerah pemilihan, baru kemudian dipakai perhitungan setiap 400.000 orang penduduk warga negara memperoleh satu kursi di DPR. Bagi Soemantri pengeterapan sistem proporsional (kendati tidak murni $100 \%$ ) sudah cukup baik; sebab dengan sistem itu ada dua hal yang dapat ditemukan, yaitu : pertama, tidak banyak suara yang hilang; kedua. PPP dan PDI masih bisa memperoleh kursi sampai $15,3 \%$ dan $10 \%$. Oleh karenanya dia berpendapat bahwa suara-suara yang mengusulkan perubahan menuju ke sistem distrik adalah kurang realistik, "minimal saat ini belum saatnya untuk menerima sistem distrik".

Pandangan Soemantri yang demikian ini sejalan dengan pandangan pakar politik Afan Gaffar. Menurutnya, jika di Indonesia dipakai sistem distrik, maka hampir seluruh kursi DPR yang diperebutkan melalui. Pemilu sebanyak 400 kursi akan diborong Golkar. Afan Gaffar dan Soemantri menunjukkan data hasil Pemilu yang lalu untuk menopang pendapatnya itu. Dikatakan bahwa jika diterapkan sistem pemilihan distrik maka pada Pemilu 1987 yang lalu Golkar akan memperoleh 396 kursi, PPP 4 kursi, sedangkan PDI tidak memperoleh satupun kursi.

Dengan mengambil contoh terbatas yaitu Jateng, Jatim dan Riau, Afan Gaffar menunjukkan tabel perolehan atas dasar perbandingan sistem distrik dan sistem proporsional.

\begin{tabular}{|c|c|c|c|c|c|c|c|c|c|c|c|}
\hline \multirow{3}{*}{$\begin{array}{l}\text { Daerah } \\
\text { Pemilihan }\end{array}$} & \multicolumn{4}{|l|}{1} & \multicolumn{6}{|c|}{ Sistem Pemilihan } & \multirow{2}{*}{ 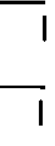 } \\
\hline & \multirow[b]{2}{*}{1} & \multicolumn{3}{|c|}{ Proporsional } & & \multicolumn{4}{|c|}{ I Pluralitas / Distrik } & & \\
\hline & & PPP & & OLKA & I PDI & 1 & PPP & & OLKAR I & I PDI & 1 \\
\hline JAT & I & 13 & 1 & 46 & I & I & 1 & 1 & 63 & 1 None & I \\
\hline JATENG & 1 & 11 & I & 39 & 18 & 1 & None & 1 & 58 & I None & I \\
\hline RIAU V & 1 & 1 & 1 & 6 & 1 None & 1 & None & 1 & 7 & I None & 1 \\
\hline
\end{tabular}


Dari data itu Afan menyatakan punya alasan kuat untuk menolak Sistem Distrik. "Dari tabel itu dapat dilihat betapa besar konsekuensi dari perubahan menuju sistem distrik dengan asumsi dasar bahwa hal-hal lainnya yang berkaitan dengan pemilu adalah ceteris paribus", tandas Afan Gaffar. Masalahnya menurut doktor lulusan Ohio State University ini bukan terletak pada sistem proporsional atau bukan, melainkan terletak pada mekanisme pemilihannya. Sebab, katanya lagi, kita harus membedakan antara electoral laws dan electoral processes. Di Indonesia electoral laws yang disasarkan pada sistem proporsional tidak ada masalah; tetapi yang ada masalah adalah electoral processesnya. "Di Indonesia ini banyak sekali orang mencampur adukkan antara electoral laws dan electoral processes", tandasnya. Menurut Afan pula, dirinya sangat keberatan jika ada upaya perubahan sistem pemilu, sebab, apapun sistem yang akan kita pilih untuk menggantikan sistem yang sekarang berlaku kalau mekanisme pemilunya sendiri tidak diubah maka perubahan itu tak akan ada artinya sama sekali. "Perubahan sistem pemilihan harus diikuti dengan komitmen untuk melaksanakan pemilihan yang seimbang, dimana semua parpol mempunyai kesempatan untuk berkompetisi secara seimbang, dimana mereka dapat dengan leluasa membentuk dan merumuskan platform politiknya, mempunyai keleluasaan untuk menentukan caloncalon yang diharapkan duduk di dalam lembaga perwakilan rakyat, mempunyai keleluasaan untuk mengadakan kampanye, dan mempunyai keleluasaan untuk memobilitas pendukungnya", kata Afan Gaffar pula.

\section{Keluhan Parpol.}

Dalam kaitan ini Afan Gaffar,menggugat pula pengeterapan "floating mass"(massa mengambang) yang dalam kenyataannya merugikan dua parpol saingan Golkar.

Ketua Umum PDI Sorjadi yang hadir dengan makalah berjudul "Program Parpol dan Golkar Dalam Rangka Rekruitment Massa Menjelang dan Pasca Pemilu" mengemukakan bahwa Sistem massa mengambang menyebabkan parpol sulit untuk mampu melaksanakan fungsinya secara intensif mengingat tingkat kematangan dan kemampuan parpol sendiri di satu pihak dan kondisi lingkungan dan masyarakat dengan berbagai latar belakang sosbud dan demografi serta geografi pada pihak lain. Dengan sistem massa mengambang kekuatan sospol akan tercabut dari akarnya yaitu rakyat sehingga akan sulit mendapat dukugan karena kesulitan berkomunikasi dengan rakyat. "Sebagai satu sistem; massa mengambang akan menyebabkan rakyat kehilangan hak politiknya untuk ikut serta dalam pengelolaan negara secara rutin dan rakyat akan kehilangan kesempatan untuk mengikuti pendidikan politik secara efektif", tandas Soerjadi.

Ismail Hasan Metareum, Ketua Umum. PPP, yang hadir dengan judul makalah "Rekruitment Massa dan Program Partai Menjelang dan Pasca Pemilu" menyatakan bahwa sebenamya PPP tidak keberatan dengan pola massa mengambang asalkan dilaksanakan secara konsekuen. Tapi masalahnya adalah kenyataan bahwa praktek massa mengambang selama ini tidak fair, ia hanya diberlakukan kepada parpol 
semata. "Rakyat di desa ternyata memang diungsikan dari kotak-kotak parpol dan diarahkan ke kotak yang satu yang bukan parpol, yang diunggulkan oleh birokrasi sebagai a single majority", kata Ismail Hasan menyindir.. "Dengan kondisi itu maka parpol merasakan bahwa yang.diambangkan bukan massa melainkan parpol (floating for political party)", tambahnya.

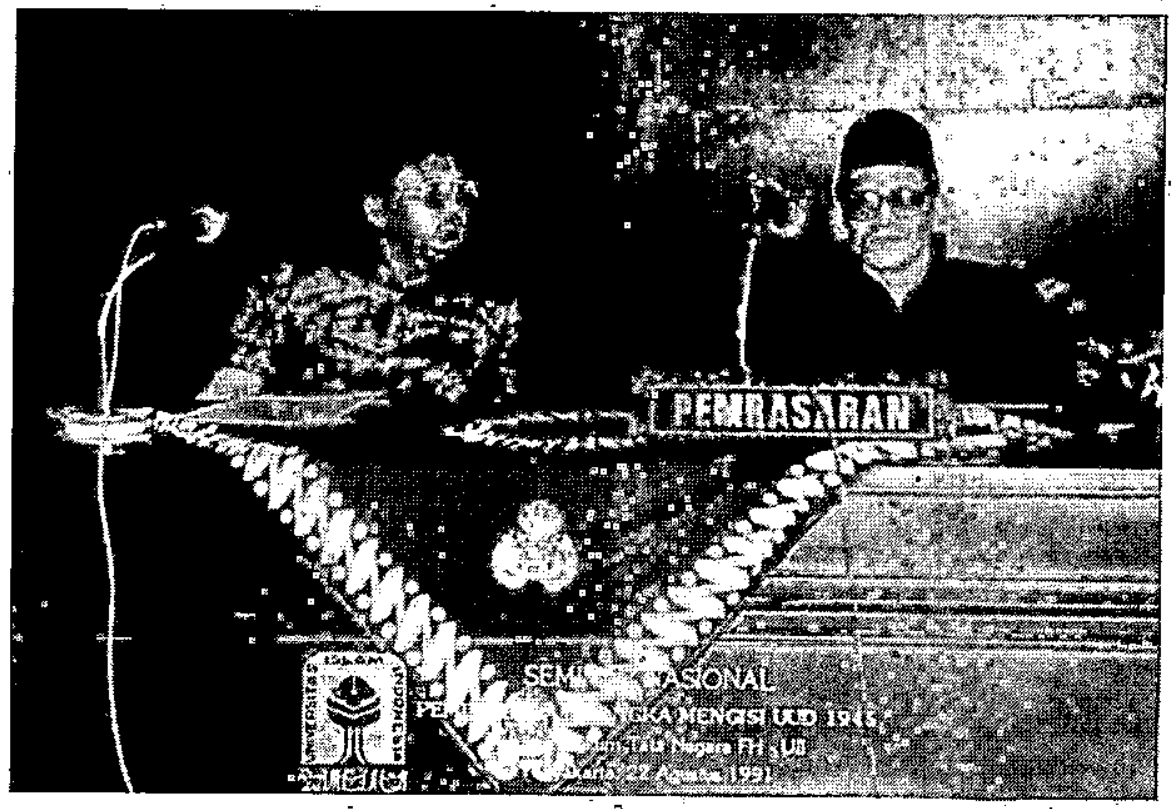

Slamet Effendi Yusuf dan Ismail Hasan Metareumparpol mengambang

Menurut Slamet Effendi Yusuf dari. DPP Golkar pelaksanaan sistem massa mengambang merupakan sesuatu yang harus dilihat dalam keseluruhan konteks kehidupan bemegara. Golkar, katanya, merumuskan kehidupan berpemerintahan dan bernegara sebagai bagian tidak terpisahkan dari perjuangannya untuk menegakkan prinsip-prinsip dasar kehidupan berbangsa dan bernegara sebagaimana kesepakatan yang telah dicapai bangsa Indonesia sejak awal kemerdekaannya. Dalam kaitan dengan rẹkruitmen. masssa, ,Golkar melihat bahwa pada umumnya massa adalah bersifat mengambang dan tidak begitu saja secara pasif dianggap sebagai anggota suatu orsospol. "Pendekatan yang demikian memungkinkan suatu anggota masyarakat politik secara aktif melakukan pilihan untuk menjadi anggota orpol tertentu", țambahnya. 
Dengan sistem massa mengambang Ketua PPP Ismail melihat bahwa parpol tak bisa melaksanakan fungsi-fungsinya secara baik. Adanya ketentuan massa mengambang telah menyebabkan terputusnya hubungan antara parpol dengan massanya di desa, sedangkan aparat birokrasi dapat menggantikan fungsi pengurus bagi yang lainnya. Lebih jauh Ismail memaparkan bahwa berdasarkan ketentuan perundang-undangan ada beberapa fungsi parpol yang bisa dicatat, yaitu :

a. Menampung dan menyalurkan pendapat dan aspirasi masyarakat.

b. Mewujudkan hak-hak politik rakyat.

c. Membina anggota-anggotanya.

d. Sebagai wadah untuk mendidik kesadaran politik rakyat.

e. Mendaftar anggota-anggotanya dan memelihara daftar anggotanya.

f. Membentuk kader yang tangguh dan berkualitas.

g. Memperjuangkan aspirasi masyarakat.

h. Memelihara komunikasi timbal balik dengan masyạrakat.

Dengan fungsi-fungsi itu maka idealnya maka tak perlu dipakai sistem massa mengambang sebab untuk melaksanakan fungsi-fungsi tersebut diperlukan forum secara formal bagi parpol di pedesaan untuk menggarap pembinaan bagi anggotaanggotanya. Tapi, "Secara formal untuk pertemuan, rapat-rapat komisaris, rapat komisaris dengan para anggota tidak tersedia untuk tingkat kecamatan dan desa sehingga pelaksanaan fungsi-fungsi tersebut terhambat secara formal. PPP merasabahwa dengan kondisi yang seperti itu maka upaya rekruitmen personal dari orsospol, terutama parpol dalam menjaring serta mengembangkan tokohtokoh/pimpinan rakyat yang berakar di masyarakat menghadapi rintangan. "Yah, sebenamya PPP tidak keberatan dengan sistem ini asal dilaksanakan secara konsekuen dan tidak hanya ditujukan kepada PPP dan PDI", kata Ismail. Pelaksanaan floatingmass ternyata merisaukan Ismail bersama PPP-nya sebab orsospol yang memperoleh payung politik protektif melalui instrumèn/fasilitas birokrasi (maksudnya Golkar, Red) mampu membina dan memelihara serta memantapkan kendali politik masyarakat desa. Tegasnya, "Pola massa mengambang yang terjadi selama ini ternyata diabaikan oleh aparat birokrasi terutama di pedesaan. Bahkan dengan pelayanan yang bersifat diskriminatif," kata Ismail.

Secara yuridis, sebenamya, tidak ada pernyataan eksplisit di dalam peraturan perundang-undangan tentang sistem floating mass ini. Tetapi pemakaian sistem ini dituntut dengan sangat kuat berdasarkan penafsiran atas beberapa materi Tap MPR No. IV/1973 (Bagian C, Bidang Politik, Butir 5) dan'UU No. 3/1985 yakni : parpol dan Golkar merupakan partai kader dengan pola massa mengambang. Bagian Tap MPR yang disebut diatas menggariskan bahwa :

"untuk mengikut sertakan rakyat secara maksimal dalam pembangunan, hendaknya rakyat terutama yang berada di desa dapat diajak untuk memusatkan perhatiannya pada pelaksanaan pembangunan dan diarahkan pada masalah-masalah konkrit, dan yang 
langsung menyangkut pembangunan." Bunyi Tap yang demikian, menurut Ismail telah mendorong terjadinya proses depolitisási rakyat pedesaan. Dengan jargon "Pembangunan yes, politik no" rakyat seolah-olah diajak untuk tidak menyenangi parpol. Apalagi UU No. 3/1975 yang kemudian diperbarui dengan UU No. 3/1985 telah mengintrodusir perbedaan nama bagi ketiga organisasi kekuatan politik (yang dua bernama parpol dan yang satu bernama golongan karya) sehingga diperoleh jalan yang mudah untuk mendiskreditkan parpol.

Alhasil, PPP merasa bahwa upaya rekruitment untuk menangguk massa pendukung harus berhadapan dengan sistem massa mengambang yang pelaksanaannya tidak konsekuen ini. Hal yang sama dirasakan oleh PDI. Ketua Umum PDI Soeryadi mengatakan bahwa dengan sistem massa mengambang sangat sulit diharapkan parpol akan mampu melaksanakan fungsinya secara intensif dengan baik. Sebagai satu sistem, massa mengambang akan menyebabkan rakyat kehilangan hak politiknya untuk ikut serta dalam pengelolaan negara secara rutin dan rakyat akan kehilangan kesempatan untuk mengikuti pendidikan politik yang secara efektif. "Dalam kondisi seperti itu maka kekuasaan politik yang secara konstitusional berada di tangan rakyat dalam praktek keseharian akan terlepas pada saat seorang warga negara telah mecoblos dalam pemilu", tandas Soeryadi. Sistem ini dalam praktek keseharian telah banyak dimanfaatkan secara tidak bertanggung jawab oleh perangkat birokrasi baik sebagai oknum maupun sebagai aparat. Banyak kebijaksanaan birokrasi maupun kasus yang benar-benar melanggar prinsip hak politik rakyat seperti monoloyalitas pegawai negeri kepada suatu orsospol, daerah bebas parpol, ancaman dan intimidasi dan sebagainya. "PDI berpendapat bahwa kepada setiap warga negara yang menjadi pegawai negeri seharusnya tetap dihormati hak dan keyakinan politiknya," tambah Soeryadi. Selanjutnya Soeryadi menyatakan begini : Pegawai negeri pada dasarnya adalah warga negara biasa yang tidak boleh dibedakan dengan warga negara yang lain dalam pelaksanaan hak politiknya. Pegawai negeri sebagai aparat pelayanan umum tidak boleh dibebani dengan tugas-tugas politik praktis, meskipun sebagai warga negara dia harus tetap dihormati keyakinan politiknya diluar tugas dinasnya. Namun jika kebebasan berpolitik ini dinilai cenderung untuk disalah gunakan atau dimanipulasikan maka PDI tidak keberatan jika kepada warga negara yang menjadi pegawai negeri, dengan UU dinyatakan tidak diberlakukan hak politiknya untuk menjadi anggota orsospol selama menjadi Pegawai Negeri sedangkan hak pilihnya tetap diberikan.

Slamet Effendi Yusuf dari Golkar menanggapi hal tersebut dengan nada kurang setuju. "Setiap Pegawai Negeri adalah anggota KORPRI. Jika KORPRI sebagai organisasi telah menyatakan sikap untuk mendukung șatu orsospol maka anggotaanggotanya harus mengikuti. Jika tidak setuju dengan keputusan organisasi maka keluar saja dari organisasi itu," kata Slamet. Artinya dalam kasus ini setiap pegawai negeri dapat melepas pekerjaannya sebagai Pegawai Negeri dan menanggalkan keanggotaannya dari KORPRI untuk kemudian menentukan pilihannya kepada setiap orsospol dengan sebebas-bebasnya. 


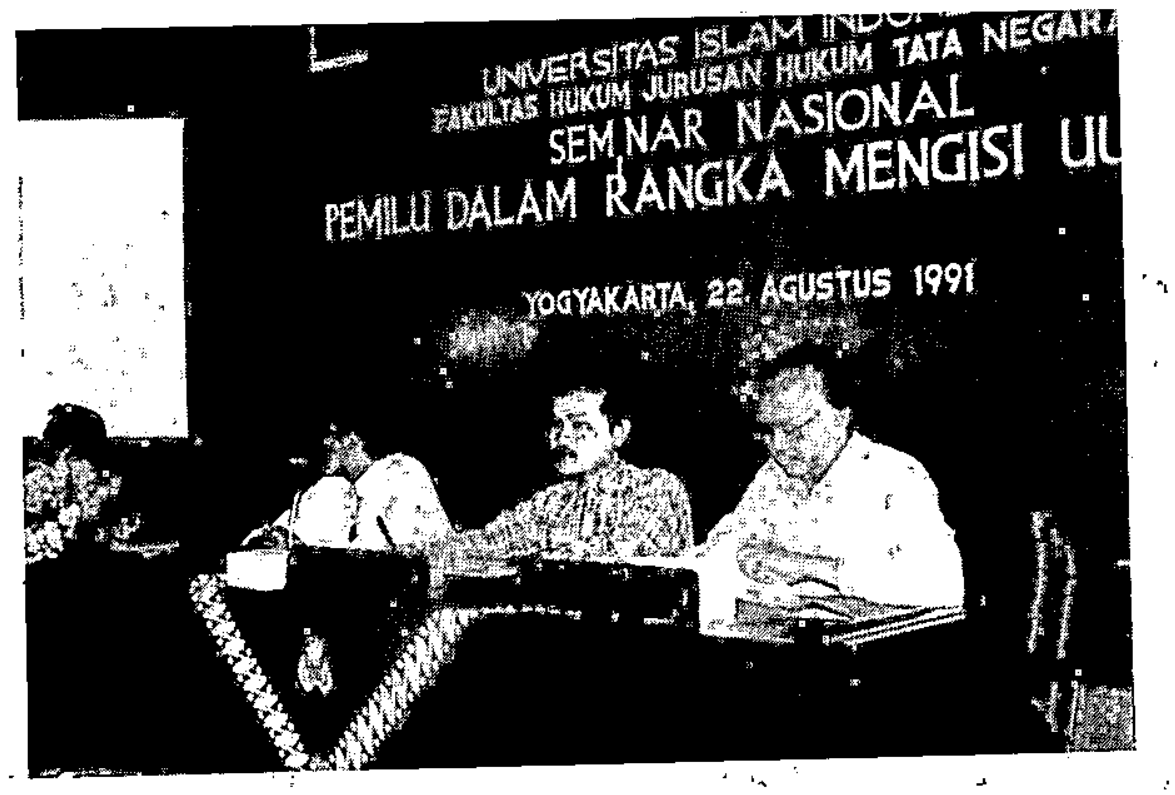

Soerjadi (kanan), hak politik dan hak pilih pegawai negeri

Memang ada paradoksa dalam pembangunan politik di Indonesia. Disatu pihak kita memerlukan partisipasi politik yang kreatif; kritis dan konstruktif dalam rangka orientasi pada modernisasi sehingga rakyat*bebas untuk menentukan pilihanpilihannya tanpa tekanan; tetapi pada pihak lain kita sangat yakin akan perlunya stabilitas politik yang mantap (rakyat tidak terjebak pada gonjang-ganjing pertentangan politik) agar kita" bisa membangun secara bertitik berat pada "pembangunan ekonomi". Soalnya kita dihadapkan pada pilihan : apakah lebih menginginkan pembangungan ekonomi ataukah lebih memilih demokratisasi kehidupan politik dengan konsekuensi terganggunya pembangunan ekonomi. Atau : adakah jalan untuk memilih keduanya secara berkesimbangan? Haruskah kita hanya memilih salah satunya ??*** (Moh. Mahfud MD)!: :" 